\title{
Degradations of Tannin and Saponin and Changes in Nutrition during Co-composting of Shell and Seed Cake of Camellia oleifera Abel
}

\author{
Jinping Zhang, ${ }^{\mathrm{a}, *}$ Yue Ying, ${ }^{\mathrm{a}}$ Xiaohua Yao, ${ }^{\mathrm{a}}$ Weihua Huang, ${ }^{\mathrm{b}}$ and Xiangsheng Tao ${ }^{\mathrm{b}}$
}

The degradation processes of tannin and saponin were studied during co-composting of the shell and seed cake of Camellia oleifera Abel. Four treatments were designed, with the dry weight of the seed cake accounting for $30 \%(\mathrm{~A} 1), 25 \%$ (A2), $20 \%$ (A3), and $10 \%$ (A4) of the shell weight. During the composting, the duration and the highest temperature of the thermophilic phase were positively correlated with the addition proportion of seed cake. The degradation rates of tannin and saponin were positively correlated with the addition proportion of seed cake, but the $\mathrm{C} / \mathrm{N}$ ratio and final tannin content were negatively correlated with it. The saponin content ultimately contributed to approximately $2 \%$ of the final compost mass. The final content of saponin and tannin decreased by 68.9 to $75.2 \%$ and 34.6 to $59.5 \%$. The organic matter and total nutrient content $\left(\mathrm{N}, \mathrm{P}_{2} \mathrm{O}_{5}\right.$, and $\left.\mathrm{K}_{2} \mathrm{O}\right)$ increased with the increasing proportion of seed cake. An addition proportion of $30 \%$ of Camellia oleifera seed cake is recommended to produce homogenous compost. Overall, the addition of the seed cake promoted the maturity, fertilizer quality, and safety of the co-compost product.

Keywords: Camellia oleifera Abel; Shell; Seed cake; Compost; Tannin; Saponin; Degradation

Contact information: a: Research Institute of Subtropical Forestry, Chinese Academy of Forestry, Hangzhou, Fuyang, China; b: Science and Technology Research Center of Edible Fungi, Qingyuan 323800, Zhejiang, China; *Corresponding author: jinpingzhang@126.com

\section{INTRODUCTION}

Camellia oleifera Abel (C. oleifera) is one of the top four woody edible oil tree species in the world and is a major economic crop in southern China (Yao et al. 2012). At the end of 2017, the cultivation area of $C$. oleifera expanded to 4.37 million hectares, with annual production of $C$. oleifera seed, oil, shell, and seed cake reaching 2.4, 0.6, 3.6, and 1.8 million tons, respectively, in China. The $C$. oleifera shell accounts for more than $60 \%$ of the weight of the fresh fruit (Zhang et al. 2015). In addition to lignocellulose that accounts for $80 \%$ of the composition, the $C$. oleifera shells also contain saponin and tannin (Zhang et al. 2018) that slowly degrade under natural conditions. The C. oleifera seed cake is the residue left from the oil extraction, which is mainly composed of crude protein, crude fat, crude fiber, saponin, tannin, ash, caffeine, etc. (Deng et al. 2004).

The contents of tannins and saponin in the $C$. oleifera shell are approximately $2.26 \%$ and $4.8 \%$, respectively (Zhang et al. 2018), and those in C. oleifera seed cake are approximately $1.5 \%$ and $15 \%$ to $25 \%$, respectively(Ding 2012). Tannins are a class of defensive secondary metabolites (Cowan 1999) that are produced during the long-term evolution of plants to prevent infection by animal feeding and pathogenic microorganisms; the tannins can inhibit microbial growth and biodegradation (McSweeney et al. 2001). 
The tannins in $C$. oleifera shell and seed cake are highly polymerized natural polyphenols that can bind to proteins or enzymes, impede the metabolism of microorganisms and inhibit the growth of microorganisms. However, some microorganisms are resistant to tannins and can even utilize tannins as the sole carbon source (Lekha and Lonsane 1997; Ai et al. 2011). On the other hand, tea saponin is a class of pentacyclic triterpenoids with a $\beta$-fragrant tree skeleton. They can be considered as a derivative of oleanane with a polyhydroquinone pentacyclic ring (Ye 2002). Tea saponin is highly toxic for cold-blooded animals (Chen et al. 2006) and can hemolyze red blood cells (Sagesaka et al. 1996).

The safe intake range for warm-blooded animals is 50 to $150 \mathrm{mg} / \mathrm{kg}$ per day, and the effective concentration for killing Lumbricina is $0.3 \mathrm{mg} / \mathrm{mL}$. Tea saponin can function as the antifeedant of Plutella xylostella, and it can also inhibit the growth of Fusarium oxysporum at concentrations higher than $0.39 \mathrm{mg} / \mathrm{mL}$ (He et al. 2007). Further, tea saponin has also been used for the control of various pests, such as Pieris rapae larvae and Plutella xylostella (Hao et al. 2010).

The direct disposal or utilization of the $C$. oleifera seed cake can cause serious environmental pollution. Most of the $C$. oleifera shell and seed cake is discarded or burned at present, causing serious environmental pollution and resource waste (Lei et al. 2019), making it important to improve the utilization efficiency of $C$. oleifera waste and explore the methods of its utilization. Composting is one of the effective methods to treat the $C$. oleifera shell and seed cake. However, the unstable components of the shell and seed, such as cellulose, hemicellulose, and lignin, as well as saponins and tannins that can inhibit the growth of microbes and plant growth (Zhang et al. 2018), significantly affect their biodegradation during composting. Therefore, studying the degradation and content changes of tannin and saponin during the composting of $C$. oleifera shell and seed cake are necessary. In this study, the effects of the addition of $C$. oleifera seed cake on the composting of $C$. oleifera shell were investigated using the shell as the raw material and the seed cake as the microbial inoculant. The physicochemical properties of the compost and the degradation of tannin and saponin during the composting were analyzed, aiming to provide the scientific foundation for the composting of $C$. oleifera shell and seed cake.

\section{EXPERIMENTAL}

\section{Compost Materials and Preparation}

The $C$. oleifera shells were collected from Zhejiang, Jinhua, Dongfanghong Forest Farm (China). The $C$. oleifera seed cake was provided by Zhejiang, Tiantai, Kangneng Tea Oil Co., Ltd. (China). Effective microorganisms (EM) were obtained from Henan Nanhua Qianmu Biotechnology Co., Ltd. (Zhengzhou, China), whose main components were Bacillus, Lactobacillus, Bifidobacterium, yeast, photosynthetic bacteria, acetic acid bacteria, Actinobacillus, and other original species.

Except for the addition of EM, laboratory-selected tannins-degrading microorganism agents (Aspergillus awamori) and saponin-degrading microbial agents (Bacillus amyloliquefaciens and Meyerozyma guilliermondii) were added in an amount of $1 \%$, respectively. The chemical compositions and primary properties of the raw materials are shown in Table 1. 
Table 1. Chemical Compositions and Properties of Raw Materials

\begin{tabular}{|c|c|c|c|}
\hline Parameters & Shell of C. oleifera & Seed Cake of C. oleifera & Urea \\
\hline Organic Matter (\%) & $83.78 \pm 4.25$ & $82.41 \pm 3.27$ & - \\
\hline Tannin (\%) & $2.26 \pm 0.12$ & $1.03 \pm 0.03$ & - \\
\hline Saponin (\%) & $4.80 \pm 0.90$ & $16.35 \pm 2.10$ & - \\
\hline Polysaccharides (\%) & $2.65 \pm 1.10$ & $14.22 \pm 1.81$ & - \\
\hline Crude Protein (\%) & $2.61 \pm 0.11$ & $7.62 \pm 0.96$ & - \\
\hline Fat (\%) & $\leqslant 1$ & $9 \pm 1.4$ & \\
\hline Total C (\%) & $48.64 \pm 2.12$ & $47.83 \pm 1.92$ & $20.03 \pm$ \\
& $0.42 \pm 0.08$ & $1.22 \pm 0.02$ & 0.12 \\
\hline Total N (\%) & $116.21 \pm 2.43$ & $39.01 \pm 1.50$ & $0.43 \pm 0.02$ \\
\hline C/N & $0.017 \pm 0.001$ & $0.161 \pm 0.032$ & 0 \\
\hline Total P (\%) & $0.86 \pm 0.02$ & $0.93 \pm 0.08$ & 0 \\
\hline Total K (\%) & $58.2 \pm 3.4$ & $5.2 \pm 1.2$ & - \\
\hline GI (\%) & $5.80 \pm 0.02$ & $5.48 \pm 0.05$ & $7.00 \pm 0.05$ \\
\hline pH & & &
\end{tabular}

a All data is expressed on a dry weight basis

\section{Composting Methods}

The $C$. oleifera shell (particle size $\leq 20 \mathrm{~mm}$ ) and seed cake (particle size $\leq 2 \mathrm{~mm}$ ) were composted in a COMPOSTER 220eco $(73 \times 115 \times 80 \mathrm{~cm}, 220 \mathrm{~L})$ (Biolan Oy, Eura, Finland), an insulated and highly ventilated ecological composting tank in the winter season with ambient temperature variation from 0 to $22{ }^{\circ} \mathrm{C}$. Double-layer polyethylene and polyurethane materials were used as an insulation layer in the tank, which can effectively maintain microbial activity and continuously compost throughout the year. The tank was equipped with a thermometer with automatic temperature measurement. The air vent was located in the middle and lower part of the composting barrel, which was connected to the outside by a pipeline. The pipeline spirally distributed near the inner wall of the tank. The outlet of the pipeline was located in the upper part of the composting barrel. The knob at the inlet and outlet of the air vent regulated the air flow. The bottom side of the composting tank had a leachate discharge pipe.

Four treatments were designed with different addition proportions of $C$. oleifera seed cake, accounting for $30 \%$ (A1), $25 \%$ (A2), $20 \%$ (A3), and $10 \%$ (A4) of the total weight (dry weight basis), with three repetitions. The initial $\mathrm{C} / \mathrm{N}$ ratio of each treatment was adjusted to 30 with urea and blended with EM (3\% of the dry weight of C. oleifera shell). The water content of each treatment was then adjusted to 55\% (Bernalet al. 2009). No adjustments of these parameters were made thereafter.

The blends were stirred thoroughly and placed in the composting tanks for aerobic fermentation. The ventilation valve of the composting tanks was rotated to the maximum ventilation level. All treatments were manually turned every 5 days outside the composter with 200 shovels in about 20 minutes each time. The compost temperature and ambient temperature were recorded every day at 3:00 pm for 76 days after the first day of composting. The $500 \mathrm{~g}$ of compost were sampled on days $0,7,20,30,45,60$, and 90 using a five-point sampling method from three locations of the fresh compost in the tank (the surface, 10-cm depth; core, 50-cm depth; and bottom, 90-cm depth). A portion of each sample was stored at $-20{ }^{\circ} \mathrm{C}$ for seed germination experiments, and the remainder was air-dried (Meng et al. 2019). 


\section{Measurements of $\mathrm{pH}$ and Moisture Content}

A total of $10 \mathrm{~g}$ of fresh sample was dispersed in deionized water at the ratio of 10:1 (v:w), and the suspension was shaken at $200 \mathrm{r} / \mathrm{min}$ for $1 \mathrm{~h}$ under ambient conditions. The $\mathrm{pH}$ was determined with a $\mathrm{pH}-2 \mathrm{~F} \mathrm{pH}$ meter (Inesa Scientific InstrumentCo., Ltd.,Shanghai, China). The moisture content was measured via drying at $105{ }^{\circ} \mathrm{C}$ for $24 \mathrm{~h}$ in a drying oven (Zhang et al. 2018).

\section{Total Organic Carbon and Elemental Analysis}

The total organic carbon (TOC) was determined using the potassium dichromate oxidation-heating method (Shuang et al. 2016). The total nitrogen (TN) was determined using the regular Kjeldahl method (Bremner 1996); total phosphorus (TP) and total potassium (TK) were determined by spectrophotometry (TU-1810, Beijing Persee General Instrument Co., Ltd. Beijing, China) and flame photometry (FP640, Shanghai Precision Instruments Co., Ltd. Shanghai, China) after $\mathrm{H}_{2} \mathrm{SO}_{4}-\mathrm{H}_{2} \mathrm{O}_{2}$ digestion, respectively (Tiquia et al. 1997). The contents of organic matter were calculated according to Eq. 1.

$$
\text { Organic matter }(\%)=\text { TOC }(\%) \times 1.724
$$

\section{Measurement of Tannin and Saponin Contents}

The tannin content $\left(C_{\mathrm{t}}\right)$ was analyzed with spectrophotometry after extraction with a water mixture as per NY/T 1600 (2008). The saponin content $\left(C_{\mathrm{s}}\right)$ was determined according to published methods (Arivalagan et al. 2013). Degradation rate of tannin and saponin during composting were calculated according to Eqs. $2 \mathrm{a}$ and $2 \mathrm{~b}$,

Degradation rate of tannin $(\%)=\frac{\left[C_{\mathrm{t}}(\%) \times D W(\mathrm{~kg})\right]_{\text {intial }}-\left[C_{\mathrm{t}}(\%) \times D W(\mathrm{~kg})\right]_{x}}{\left[C_{t}(\%) \times D W(\mathrm{~kg})\right]_{\text {intial }}}$

Degradation rate of saponin $(\%)=\frac{\left[C_{\mathrm{S}}(\%) \times D W(\mathrm{~kg})\right]_{\mathrm{intial}}-\left[C_{\mathrm{S}}(\%) \times D W(\mathrm{~kg})\right]_{\mathrm{X}}}{\left[C_{\mathrm{s}}(\%) \times D W(\mathrm{~kg})\right]_{\text {intial }}}$

wherethe $D W$ is dry weight $(\mathrm{kg})$ of the treatment (A1/A2/A3/A4) and $x$ is the day of sample collection.

\section{Seed Germination Index (GI)}

The seed germination index (GI) assay was undertaken using seeds of Brassica chinensis var.chinensis. The $20 \mathrm{~g}$ of fresh sample was added to $200 \mathrm{~mL}$ of distilled water, thoroughly shaken for $1 \mathrm{~h}$, leached at $30{ }^{\circ} \mathrm{C}$ for $24 \mathrm{~h}$, and then filtered. A total of $6 \mathrm{~mL}$ of the filtrate were added to a $9-\mathrm{cm}$ culture dish covered with a filter paper. Twenty good quality seeds were seeded in the culture dish and incubated in a $20.0 \pm 1.0{ }^{\circ} \mathrm{C}$ incubator. The seed germination rate was measured after $24 \mathrm{~h}$. Each treatment was repeated three times, with distilled water used as the control. The GI was calculated according to Eq. 3:

$$
G I(\%)=\frac{\text { Germination rate in compost extract }(\%) \times \text { Root length }(\mathrm{cm})}{\text { Germination rate in distilled water }(\%) \times \text { Root length }(\mathrm{cm})}
$$

\section{Statistical Analysis}

Pearson's correlation analysis was completed using the SPSS 20.0 software (IBM Co., Armonk, NY, USA), and the figures were drawn on ORIGIN 8.0 computer program. (OriginLab, Northampton, USA). The results presented in this study were the mean values \pm standard deviations. Bivariable square Pearson's correlation analysis was applied to disclose the relationship between the proportion of seed cake, degradation 
rate/initial content/final content of tannin and saponin, initial crude protein content, and the initial polysaccharides content. Significance was assumed if the $p<0.05$.

\section{RESULTS AND DISCUSSIONS}

\section{Compost Temperature}

Temperature is one of the important compost maturity indexes. It is closely related to the properties of raw material, microbial activity, composting cycle, and compost maturity (Bustamante et al. 2008; Gu et al. 2015). In general, composting undergoes four phases: the mesophilic phase, the thermophilic phase $\left(>50{ }^{\circ} \mathrm{C}\right)$, the cooling phase, and the maturing phase. Temperatures over $55{ }^{\circ} \mathrm{C}$ kill pathogenic microorganisms, eggs, and weed seeds, producing harmless composts. However, microbial activities drop rapidly at temperatures above $63{ }^{\circ} \mathrm{C}$ (Bernal et al. 2009). The temperatures of all compost piles during composting were much higher than the ambient temperature (Fig. 1), indicating that the ambient temperature had no obvious effects on the composting. The initial temperatures for the four treatments were all $10 \pm 0.8^{\circ} \mathrm{C}$ (Fig. $1)$.

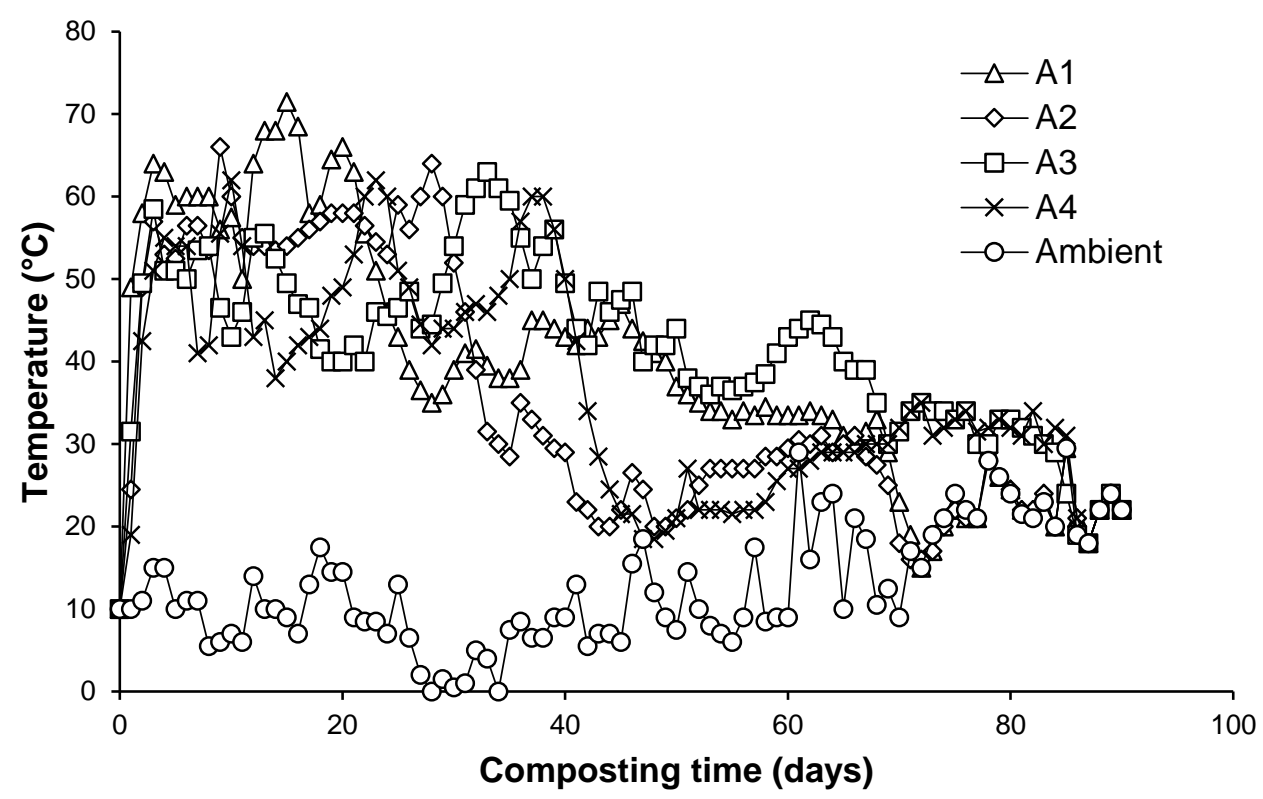

Fig. 1. Temperature profiles of the compost during composting

The temperature reached over $50{ }^{\circ} \mathrm{C}$ on day 2 (A1) or day 3 (the other treatments). The durations of the thermophilic phase were 24, 20, 17, and 17 days for A1, A2, A3, and $\mathrm{A} 4$, respectively, which reached record high temperatures of $71.5{ }^{\circ} \mathrm{C}, 66^{\circ} \mathrm{C}, 63{ }^{\circ} \mathrm{C}$, and $62{ }^{\circ} \mathrm{C}$, respectively. The days with temperatures higher than $55^{\circ} \mathrm{C}$ were $20,18,10$, and 3 , and the longest duration of temperatures above $55^{\circ} \mathrm{C}$ were 11 days, 7 days, 6 days, and 3 days for A1, A2, A3, and A4, respectively. These observations suggested that the higher contents of seed cake in the compost caused faster temperature increase, a longer thermophilic phase, and higher maximum temperatures. As shown in Table 1, the seed cake contained much more polysaccharides and crude protein than the shell. The contents of polysaccharides and crude protein in the four treatments were in the order of A1 > A2 $>$ A3 > A4. Polysaccharides and proteins are nutrients that are easily used by microorganisms during composting. Their degradation usually occurs during the 
mesophilic phase and in the early period of thermophilic phase (Zhang et al. 2016). Fatty acids are also nutrients that microorganisms can easily use (Dignacet al. 2005). Seed cake of $C$. oleifera, although pressed to remove oil, still contains a high fat content (Table 1) and it is an effective source of fatty acids. Therefore, the duration of the thermophilic phase and the highest temperature were probably affected by the contents of polysaccharides, crude protein, and fatty acids in $C$. oleifera shell and seed cake.

\section{The pH Results}

The $\mathrm{pH}$ is one of the important factors affecting the growth and reproduction of microorganisms. The optimum $\mathrm{pH}$ for the growth of most microorganisms is 6.5 to 7.5. The $\mathrm{pH}$ values of treatments $\mathrm{A} 1, \mathrm{~A} 2, \mathrm{~A} 3$, and A4, respectively, increased from the initial values of $5.82,5.98,6.04$, and 6.06 to $7.86,7.73,7.92$, and 7.74 at day 30 . They slightly decreased to 7.65, 7.60, 7.22, and 7.06 at day 60; and they remained stable thereafter (Fig. 2). Because of the acidic ingredients in the shell and seed cake of $C$. oleifera (Table 1 ), and/or the production of organic acids in the anaerobic fermentation of the raw materials due to poor air permeability during stacking (Said-Pullicino et al. 2007), the initial $\mathrm{pH}$ values of the composts were acidic. With the development of composting, organic acids were degraded or volatilized, and the free ammonia compounds were released by protein degradation, resulting in alkaline $\mathrm{pH}$ values (Kalamdhad and Kazmi 2009). With the increase in temperature, the ammonia compounds were continuously volatilized. During the maturing phase of composting, some unstable compounds are gradually decomposed or converted into complex cyclic compounds, such as a humuslike substance, which moves the composting to maturity, and the stacking $\mathrm{pH}$ value consequently becomes stable (Bernal et al. 2009).

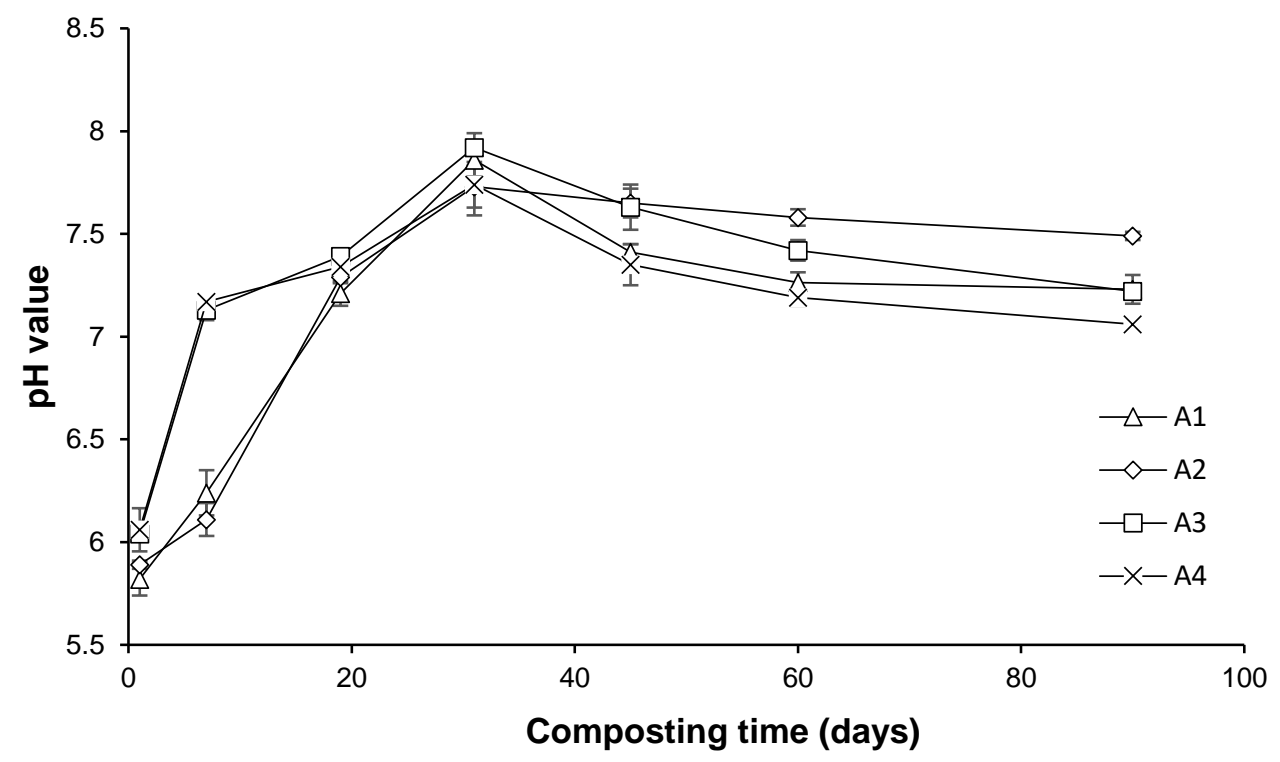

Fig. 2. Changes in $\mathrm{pH}$ value during composting

\section{Tannin and Saponin}

The tannin contents of the four treatments had a similar trend of decreasing linearly with the composting time (Fig. 3). At the end of the experiment, the tannin contents of the four treatments were in the order of A1<A2<A3<A4, with the values of $0.761 \%, 0.997 \%, 1.183 \%$, and $1.406 \%$, respectively (Table 1 ). 
Table 2. Pearson's Correlation Analysis among Proportion of Seed Cake, Tannin, and Saponin DuringComposting Process ( ${ }^{*} \mathrm{p}<$ $\left.0.05 ;{ }^{* *} \mathrm{p}<0.01\right)$

\begin{tabular}{|c|c|c|c|c|c|c|c|c|c|}
\hline & $\begin{array}{l}\text { Proportion } \\
\text { of Seed } \\
\text { Cake }\end{array}$ & $\begin{array}{l}\text { Degradation } \\
\text { Rate of } \\
\text { Tannin }\end{array}$ & $\begin{array}{l}\text { Degradation } \\
\text { Rate of } \\
\text { Saponin }\end{array}$ & $\begin{array}{c}\text { Initial } \\
\text { Tannin } \\
\text { Content }\end{array}$ & $\begin{array}{c}\text { Initial } \\
\text { Saponin } \\
\text { Content }\end{array}$ & $\begin{array}{l}\text { Final } \\
\text { Tannin } \\
\text { Content }\end{array}$ & $\begin{array}{c}\text { Final } \\
\text { Saponin } \\
\text { Content }\end{array}$ & $\begin{array}{l}\text { Initial } \\
\text { Crude } \\
\text { Protein } \\
\text { Content }\end{array}$ & $\begin{array}{c}\text { Initial } \\
\text { Polysaccharides } \\
\text { Content }\end{array}$ \\
\hline $\begin{array}{l}\text { Proportion of } \\
\text { Seed Cake }\end{array}$ & 1 & $0.988^{*}$ & $0.965^{*}$ & $-0.999^{* *}$ & $0.998^{* *}$ & $-0.995^{\star *}$ & 0.899 & $0.999^{* *}$ & $0.998^{* *}$ \\
\hline $\begin{array}{l}\text { Degradation } \\
\text { Rate of } \\
\text { Tannin }\end{array}$ & & 1 & $0.974^{*}$ & $-0.987^{*}$ & $0.987^{*}$ & $-0.998^{* *}$ & 0.827 & $0.978^{*}$ & $0.978^{*}$ \\
\hline $\begin{array}{l}\text { Degradation } \\
\text { Rate of } \\
\text { Saponin }\end{array}$ & & & 1 & $-0.977^{*}$ & $0.977^{*}$ & $-0.979^{*}$ & 0.769 & $0.961^{*}$ & $0.961^{*}$ \\
\hline $\begin{array}{l}\text { Initial Tannin } \\
\text { Content }\end{array}$ & & & & 1 & $-1.000^{* *}$ & $0.996^{* *}$ & -0.883 & $-0.998^{* *}$ & $-0.998^{* *}$ \\
\hline $\begin{array}{c}\text { Initial } \\
\text { Saponin } \\
\text { Content }\end{array}$ & & & & & 1 & $-0.996^{* *}$ & 0.882 & $0.998^{* *}$ & $0.997^{* *}$ \\
\hline $\begin{array}{l}\text { Final Tannin } \\
\text { Content }\end{array}$ & & & & & & 1 & -0.852 & $-0.989^{*}$ & $-0.989^{*}$ \\
\hline $\begin{array}{c}\text { Final } \\
\text { Saponin } \\
\text { Content }\end{array}$ & & & & & & & 1 & .913 & 0.913 \\
\hline $\begin{array}{l}\text { Initial Crude } \\
\text { Protein } \\
\text { Content }\end{array}$ & & & & & & & & 1 & $1.000^{* *}$ \\
\hline $\begin{array}{c}\text { Initial } \\
\text { Polysacchari } \\
\text { des Content }\end{array}$ & & & & & & & & & 1 \\
\hline
\end{tabular}




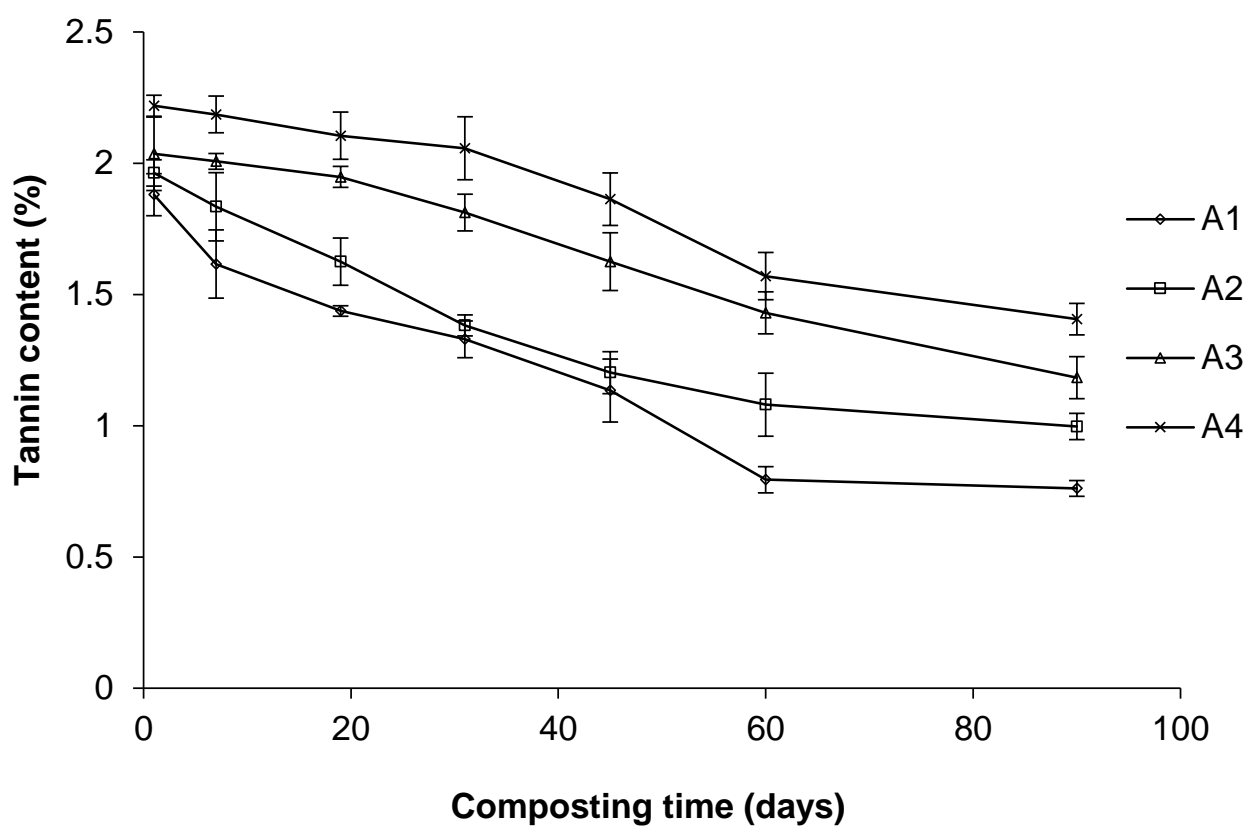

Fig. 3. Changes in tannin content during composting

The corresponding degradation percentages were 59.5\%, 49.2\%, 41.9\%, and $34.6 \%$ (Fig. 4). As the proportion of the seed cake increased in the four treatments, the final tannin content decreased and the tannin degradation rate increased, both of which were affected significantly $(\mathrm{r}=0.012, \mathrm{P}<0.05, \mathrm{r}=0.005, \mathrm{P}<0.01$, respectively) by the proportion of the seed cake, which might be attributed to the combination of protein and tannin (Table 2). Table 2 shows that there was a significant positive correlation between the initial protein content and tannin degradation rate $(\mathrm{r}=0.978, \mathrm{P}<0.05)$. Protein is an important nutrient for microorganisms to provide heat for the compost to enter the thermophilic phase (Bernal et al. 2009). Tannin can combine with protein to form an insoluble complex, which affects the degradation ability of microorganisms and the degradability of protein in the compost (Ruan et al. 2006).

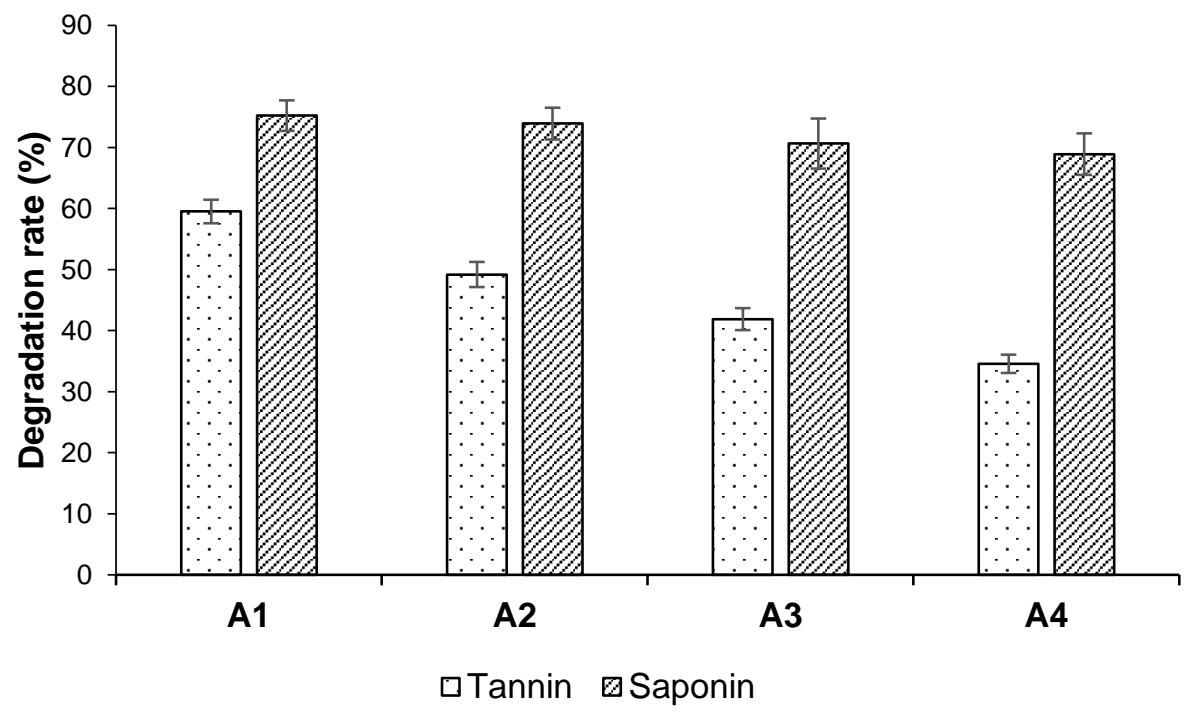

Fig. 4. Degradation rates of tannin and saponin during composting 
At the beginning of this experiment, the crude protein contents of the four treatments were in the order of $\mathrm{A} 1>\mathrm{A} 2>\mathrm{A} 3>\mathrm{A} 4$, and their tannin contents were A4 > $\mathrm{A} 3>\mathrm{A} 2>\mathrm{A} 1$ (Table 1). It could be seen that the tannin-protein binding ratio was the highest in A4, and the protein available by microorganisms was the least. Therefore, the treatments with higher tannin contents had a longer initial phase and a shorter thermophilic phase. In addition, polysaccharide content was also significantly correlated with the final content and degradation rate of tannins $(r=-0.989, \mathrm{P}<0.05$, and $\mathrm{r}=0.978$, $\mathrm{P}<0.05)$. Because polysaccharide was one of the main nutrients of microorganisms, high polysaccharide content increased microbial activity and thus accelerated the degradation of tannins.

Figure 5 shows the changes in the saponin contents in the four experimental groups with composting time. The initial saponin contents followed the order of A1 > A2 $>$ A3 > A4 and exhibited the decreasing trends with the composting time. The saponin degradation rate increased with the increase in seed cake content. The final degradation percentages of the groups A1, A2, A3, and A4 were $75.2 \%, 73.9 \%, 70.6 \%$, and $68.9 \%$, respectively (Fig. 4). The saponin degradation rate and proportion of seed cake of the four treatments showed negative correlations $(\mathrm{r}=0.965, \mathrm{P}<0.05)$. The final saponin contents in the compost products were all approximately 1.81 to $2.07 \%$, and there was no significant correlation to the initial proportion of $C$. oleifera seed cake (Table 2). After repeated experiments, the saponin content of the final compost product was always maintained at about $2 \%$. Based on this, the authors speculate thatthe concentration was too low, such thatmicroorganisms could not make use of it when the saponin content in the compost was reduced to about $2 \%$. It is difficult for microorganisms capable of degrading serotonin to take saponin in the heap or to choose other richer organic matter as the decomposition target, so that the final saponin concentration of each group was maintained at the same low concentration level, that is, the saponin under this condition limit concentration of biodegradability( $\mathrm{Li}$ et al. 2006). This concentration may be used as a criterion for judging the completion of saponin biodegradation.

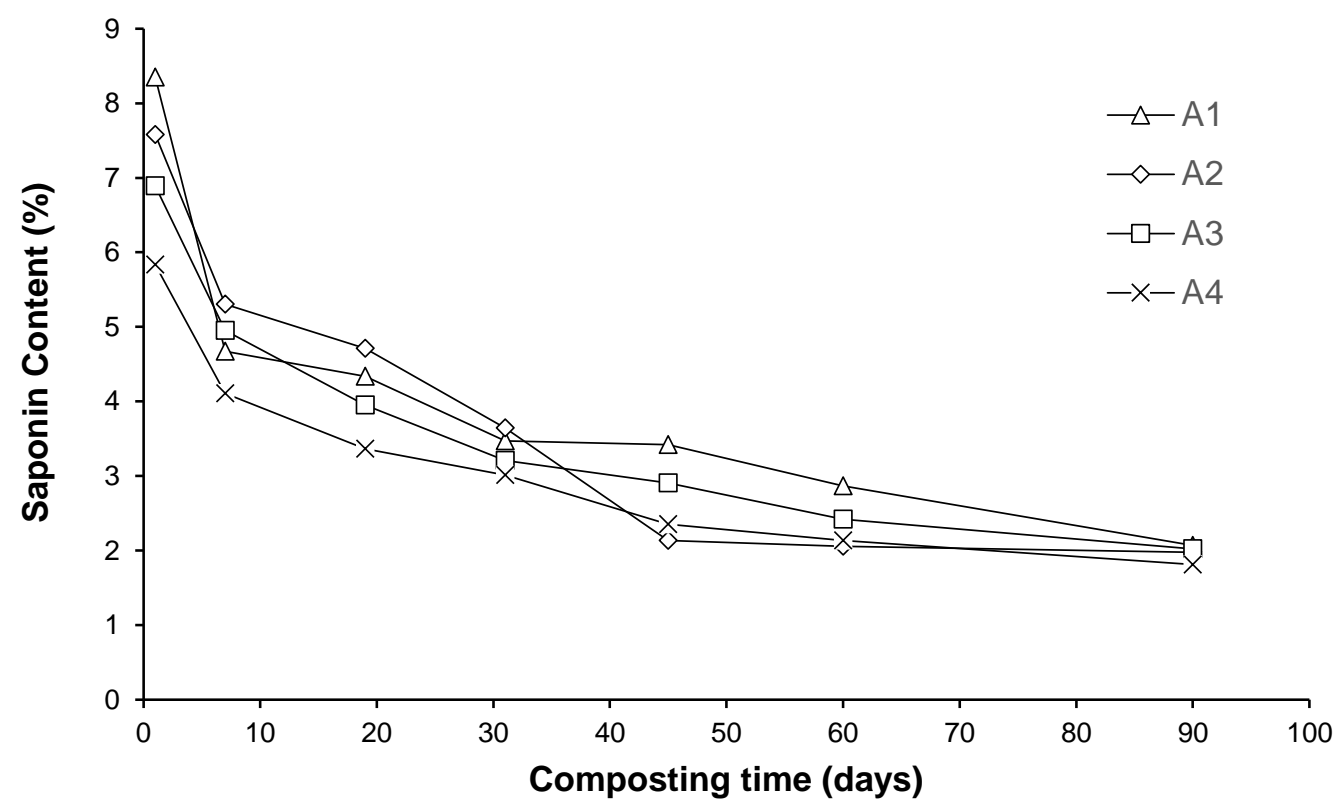

Fig. 5. Changes in saponin content during composting 


\section{Chemical Composition}

Table 3 lists the chemical properties of the final compost product of each group at the $90^{\text {th }}$ days. The moisture contents in the compost products of all four groups were less than $30 \%$. The organic matter contents were greater than $50 \%$ and the $\mathrm{pH}$ was between 7.06 and 7.61. The GI values of the four treatments were all above $85 \%$, which meant that the final compost products were safe for the growth of plants.

According to NY525 (2012), the total nutrient contents were calculated as the sum of the content of $\mathrm{N}, \mathrm{P}_{2} \mathrm{O}_{5}$, and $\mathrm{K}_{2} \mathrm{O}$ on a dry weight basis (Table 3). The total nutrient contents $\left(\mathrm{N}, \mathrm{P}_{2} \mathrm{O}_{5}\right.$, and $\left.\mathrm{K}_{2} \mathrm{O}\right)$ are important components to promote plant growth and an important standard for judging quality of compost products, which of the four treatments were less than 5\% and increased with increased addition proportion of seed cake. Therefore, the final compost products could be mixed with fertilizer (phosphate fertilizer, potassium fertilizer, and urea, etc.) if applied as fertilizer or amendment. The total nutrients represented an increase of 2.67, 2.06, 2.03, and 1.95 times as much as the initial total nutrient contents of A1, A2, A3, and A4, respectively, for part of carbon and nitrogen was consumed and converted into carbon dioxide, ammonia, or assimilated by organisms (Bernal et al. 1998; Paré, et al. 1998).

Compost maturity takes place at $\mathrm{C} / \mathrm{N}<20$, and the higher the degree of maturity is, the closer the $\mathrm{C} / \mathrm{N}$ ratio is to 10 (the $\mathrm{C} / \mathrm{N}$ ratio of humus) (Golueke 1981). The $\mathrm{C} / \mathrm{N}$ ratios of the compost products of $\mathrm{A} 1, \mathrm{~A} 2, \mathrm{~A} 3$, and $\mathrm{A} 4$ were 18.52, 19.71, 21.55, and 25.52, respectively. The product of $\mathrm{A} 1$ met the standard of compost maturity most closely.

Table. 3. Chemical Properties of the Composts ${ }^{a}$

\begin{tabular}{|c|c|c|c|c|c|}
\hline \multicolumn{6}{|c|}{ Initial Chemical Properties of the Compost } \\
\hline Parameters & A1 & $\mathrm{A} 2$ & A3 & A4 & \\
\hline Moisture (\%) & $55.0 \pm 1.0$ & $55.0 \pm 1.0$ & $55.0 \pm 1.0$ & $55.0 \pm 1.0$ & \\
\hline Organic Matter (\%) & $83.4 \pm 1.8$ & $83.5 \pm 2.1$ & $83.5 \pm 1.1$ & $83.7 \pm 1.7$ & \\
\hline Total N (\%) & $0.62 \pm 0.03$ & $0.58 \pm 0.020$ & $0.55 \pm 0.01$ & $0.49 \pm 0.04$ & \\
\hline Total $\mathrm{P}_{2} \mathrm{O}_{5}(\%)$ & $0.12 \pm 0.01$ & $0.11 \pm 0.02$ & $0.09 \pm 0.01$ & $0.07 \pm 0.01$ & \\
\hline Total $\mathrm{K}_{2} \mathrm{O}(\%)$ & $1.05 \pm 0.04$ & $1.05 \pm 0.071$ & $1.04 \pm 0.01$ & $1.03 \pm 0.03$ & \\
\hline Total Nutrients (\%) & $1.79 \pm 0.03$ & $1.73 \pm 0.021$ & $1.69 \pm 0.01$ & $1.59 \pm 0.01$ & \\
\hline $\mathrm{pH}$ & $5.82 \pm 0.03$ & $5.89 \pm 0.056$ & $6.04 \pm 0.04$ & $6.06 \pm 0.01$ & \\
\hline C/N Ratio & 30 & 30 & 30 & 30 & \\
\hline GI (\%) & $15.0 \pm 2.3$ & $12.1 \pm 3.6$ & $67.1 \pm 1.7$ & $86.3 \pm 2.3$ & \\
\hline \multicolumn{5}{|c|}{ The Final Chemical Properties of the Compost } & \multirow{2}{*}{$\begin{array}{c}\text { China Organic } \\
\text { Fertilizer }^{\mathrm{b}}\end{array}$} \\
\hline Parameters & A1 & A2 & A3 & A4 & \\
\hline Moisture (\%) & $26.5 \pm 1.1$ & $25.8 \pm 0.9$ & $25.3 \pm 1.2$ & $25.1 \pm 0.4$ & $\leqslant 30$ \\
\hline Organic Matter (\%) & $51.36 \pm 2.1$ & $52.13 \pm 1.8$ & $50.72 \pm 2.2$ & $50.44 \pm 1.9$ & $\geqslant 45$ \\
\hline Total N (\%) & $2.51 \pm 0.06$ & $1.64 \pm 0.04$ & $1.84 \pm 0.05$ & $1.46 \pm 0.05$ & - \\
\hline Total $\mathrm{P}_{2} \mathrm{O}_{5}(\%)$ & $0.34 \pm 0.04$ & $0.25 \pm 0.03$ & $0.17 \pm 0.02$ & $0.12 \pm 0.03$ & - \\
\hline Total $\mathrm{K}_{2} \mathrm{O}(\%)$ & $1.95 \pm 0.05$ & $1.68 \pm 0.06$ & $1.43 \pm 0.04$ & $1.52 \pm 0.04$ & - \\
\hline Total Nutrients (\%) & $4.79 \pm 0.12$ & $3.57 \pm 0.07$ & $3.44 \pm 0.09$ & $3.10 \pm 0.03$ & $\geqslant 5$ \\
\hline $\mathrm{pH}$ & $7.23 \pm 0.04$ & $7.61 \pm 0.05$ & $7.22 \pm 0.03$ & $7.06 \pm 0.07$ & 5.5 to 8.5 \\
\hline C/N Ratio & $18.52 \pm 1.02$ & $19.71 \pm 2.11$ & $121.55 \pm 1.20$ & $25.52 \pm 0.09$ & - \\
\hline $\mathrm{GI}(\%)$ & $124.0 \pm 2.5$ & $137.5 \pm 4.3$ & $158.7 \pm 2.6$ & $122.3 \pm 2.2$ & $\geqslant 85$ \\
\hline
\end{tabular}

a Except for moisture, all data are expressed on a dry weight basis; ${ }^{b}$ According to Chinese standard for organic fertilizer NY 525 (2012) 
Table 3 shows that after composting, the content of organic matter decreased in all four treatments, which was probably due to the degradation of most of the hemicellulose and some of the cellulose and lignin. Total $\mathrm{N}, \mathrm{P}_{2} \mathrm{O}_{5}, \mathrm{~K}_{2} \mathrm{O}$, and total nutrients increased, which was due to the initial addition of urea used to regulate the $\mathrm{C} / \mathrm{N}$ ratio, and the dry weight loss of compost products was up to $30 \%$. These results indicated that the nutrient content was positively correlated with the initial seed cake content and negatively with the $\mathrm{C} / \mathrm{N}$ ratio of the final compost products (Table 3 ). The higher the included proportion of seed cake content was, the higher degree the compost maturity according to $\mathrm{C} / \mathrm{N}$ ratio. The compost products met the criteria of the Chinese Standard of Organic Fertilizer NY 525 (2012), but the total nutrients was less than 5\%, which does not meet the standard.It can be mixed with other single-element fertilizers (such as nitrogen fertilizer, potassium fertilizer, phosphate fertilizer, etc.) according to the needs of the land and crops to reduce the use of chemical synthetic fertilizers, improve land fertility, and prevent land salinization.

\section{CONCLUSIONS}

1. The high temperature duration and highest temperature during the co-composting of Camellia oleifera shell and seed cake were mainly affected by the addition of seed cake because of its polysaccharides and crude protein.

2. The addition proportion of seed cake was negatively correlated with the tannin content in the final compost product, and positively correlated with the degradation rate of tannin and saponin. All the saponin content in the final compost was 1.81 to $2.07 \%$. After 90 days of composting, the tannin degradation percentages of A1, A2, $\mathrm{A} 3$, and A4 were $59.5 \%, 49.2 \%, 41.9 \%$, and $34.6 \%$ respectively, and the saponin degradation percentages were $75.2 \%, 73.9 \%, 70.6 \%$, and $68.9 \%$, respectively.

3. The addition proportion of seed cake was negatively correlated with the $\mathrm{C} / \mathrm{N}$ ratio in the final compost product. The compost products met the criteria of the Chinese Standard of Organic Fertilizer NY 525 (2012) except total nutrients. An addition proportion of $30 \%$ of Camellia oleifera seed cake is recommended to produce homogenous compost in the study.

\section{ACKNOWLEDGEMENTS}

The authors are grateful for the financial support (Grant No. 2017C02022) of the Provincial Department of Science and Technology of Zhejiang, China.

\section{REFERENCES CITED}

Ai, Q., Miano, Y., and Mai, K. (2011). "The anti-nutritional effects and degradations of dietary tannins: A review," Periodical of Ocean University of China 41(1/2), 33-40. DOI:10.16441/j.cnki.hdxb.2011.zl.005 
Arivalagan, M., Gangopadhyay, K. K., and Kumar, G. (2013). "Determination of steroidal saponins and fixed oil content in fenugreek (Trigonella foenum-graecum) genotypes," Indian Journal of Pharmaceutical Sciences 75(1), 110-113.

Bernal, M. P., Alburquerque, J. A., and Moral, R. (2009). "Composting of animal manures and chemical criteria for compost maturity assessment: A review," Bioresource Technology 100(22), 5444-5453. DOI: 10.1016/j.biortech.2008.11.027

Bernal, M. P., Sanchez, M. A., Paredes, C., and Roig, A. (1998). "Carbon mineralization from organic wastes at different composting stages during their incubation with soil," Agriculture, Ecosystems and Environment 69(3), 175-189. DOI: 10.1016/S01678809(98)00106-6

Bremner, J. M. (1996). "Nitrogen-total,” in: Methods of Soil Analysis. Part 3 - Chemical Methods, D. L. Sparks (ed.), SSSA Inc., Madison, WI, USA, pp. 1085-1122.

Bustamante, M. A., Paredes, C., Marhuenda-Egea, F. C., Perez-Espinosa, A., Bernal, M. P., and Moral, R. (2008). "Co-composting of distillery wastes with animal manures: Carbon and nitrogen transformations in the evaluation of compost stability," Chemosphere 72(4), 551-557.DOI: 10.1016/j.chemosphere.2008.03.030

Chen, J., He, X., Li, G., Chen, H., Wu, J., and Guo, Y. (2006). "Study on toxicities of tea saponin medicament to some of the common freshwater fish and shrimp," Freshwater Fisheries 36(1), 28-31.

Cowan, M. M. (1999). "Plant products as antimicrobial agents," Clinical Microbiology Reviews 12(4), 564-582. DOI: 10.1128/CMR.12.4.564

Deng, G., Peng, C., and Lu, F. (2004). "A study on the comprehensive utilization of oiltea-cake," Guangzhou Food Science and Technology 41(3), 130-132.

Dignac, M. F., Houot, S., Cédric Francou, and Derenne, S. (2005). "Pyrolytic study of compost and waste organic matter," Organic Geochemistry 36(7), 1054-1071. DOI: 10.1016/j.orggeochem.2005.02.007

Ding, L. (2012). Study on Utilizing and Tea Saponin Degradation in Camellia Meal, Master's Thesis, Central South University of Forestry and Technology, Hunan, China.

Golueke, C. G. (1981). "Principle of biological resource recovery," BioCycle 22, 36-40.

Gu, S., Cai, H., Yan, L., Nie, Y., Cui, K., Wang, F., and He, X. (2015). "Study on different $\mathrm{C} / \mathrm{N}$ ratio of aerobic composting between chicken manure and rice husk," Journal of Northeast Agricultural University 46(4), 51-58.

DOI:10.19720/j.cnki.issn.1005-9369.2015.04.008

Hao, W., Zeng, Y., Hu, M., Li, H., and Ji, D. (2010). "Research progress on application of tea sapoonin in presticides," Agrochemicals 49(2), 90-96.

He, X., Gao, J., and Shao, J. (2007). "Acute toxicity effect on earthworm, Plutella xylostella and Fusarium oxysporum by tea saponin," Journal of Fuzhou University (Natural Science) 35(5), 785-788.

Kalamdhad, A. S., and Kazmi, A. A. (2009). "Effects of turning frequency on compost stability and some chemical characteristics in a rotary drum composter," Chemosphere 74(10), 1327-1334. DOI: 10.1016/j.chemosphere.2008.11.058

Lei, Z., Wang, S., Fu, H., Gao, W., Wang, B., Zeng, J., and Xu, J. (2019). “Thermal pyrolysis characteristics and kinetics of hemicellulose isolated from Camellia oleifera shell," Bioresource Technology 282, 228-235. DOI: 10.1016/j.biortech.2019.02.131

Lekha, P. K., and Lonsane, B. K. (1997). "Production and application of tannin acyl hydrolase: State of the art," Advances in Applied Microbiology 44(27), 215-260. DOI: 10.1016/s0065-2164(08)70463-5 
Li, J., Zhao, Q., Sun, X., Lin, D. (2006). "Factors affecting kinetic threshold concentration of biodegradation," Journal of East China University of Science and Technology (Natural Science Edition) (3), 309-312.

McSweeney, C. S., Palmer, B., McNeill, D. M., and Krause, D. O. (2001). "Microbial interactions with tannins: Nutritional consequences for ruminants," Animal Feed Science and Technology 91(1-2), 83-93. DOI: 10.1016/S0377-8401(01)00232-2

Meng, X., Liu, B., Zhang, H., Wu, J., Yuan, X., and Cui, Z. (2019). "Co-composting of the biogas residues and spent mushroom substrate: Physicochemical properties and maturity assessment," Bioresource Technology 276, 281-287. DOI: 10.1016/j.biortech.2018.12.097

NY 525(2012). “Organic fertilizer," People’s Republic of China Agricultural Industry Standard, Beijing, China.

NY/T 1600(2008). "Determination of tannin content in fruit, vegetable and derived product spectrophotometry method," People's Republic of China Agricultural Industry Standard, Beijing, China.

Paré, T., Dinel, H., Schnitzer, M., and Dumontet, S. (1998). "Transformations of carbon and nitrogen during composting of carbon and nitrogen of animal manure and shredded paper," Biology and Fertility of Soils 26(3), 173-178. DOI: $10.1007 / \mathrm{s} 003740050364$

Ruan, Z., and Xiang, P. (2006). "Antimicrobial activity of tannic compounds," ActaAgriculturae Boreali-Sinica 21(S1), 16-19.

Said-Pullicino, D., Erriquens, F. G., and Gigliotti, G. (2007). "Changes in the chemical characteristics of water-extractable organic matter during composting and their influence on compost stability and maturity," Bioresource Technology 98(9), 18221831. DOI: 10.1016/j.biortech.2006.06.018

Sagesaka, M. Y., Sugiura, T., Miwa, Y., Yamaguch, K., and Kyuki, K. (1996). "Effect of tea leaf saponin on blood pressure of spontaneously hypertensive rats," Yakugaku Zasshi 116(5), 388-395.

Shuang, L., Ni, S., Du, J., Teng, Z., and Shi, C. (2016). “Determination of organic carbon in geochemical soil sample by potassium dichromate oxidation-heating method," Anhui Chemical Industry 42(4), 110-112. DOI:10.3969/j.issn.1008553X.2016.04.041

Tiquia, S. M., Tam, N. F. Y., and Hodgkiss, I. J. (1997). "Effects of turning frequency on composting of spent pig-manure sawdust litter," Bioresource Technology 62(1-2), 3742. DOI: 10.1016/S0960-8524(97)00080-1

Yao, X., Wang, K., Ren, H., and Lin, P. (2012). The Research on Oil Camellia Resources and Its Scientific Utilization, Science Press, Beijing, China.

Ye, X. (2002). "Development and utilization of tea saponin," Chemical Production and Technology 9(2), 6-8.

Zhang, J., Wang, Z., Du, M., Yao, X., and Hu, L. (2015). "Physicochemical properties of Camellia nutshell and its thermal degradation characteristics," BioResources 10(1), 647-659. DOI: 10.15376/biores.10.1.647-659

Zhang, J., Ying, Y., Li, X., and Yao, X. (2018). "Evaluation of three kinds of nutshell with respect to utilization as culture media," BioResources 13(4), 7508-7518. DOI: 10.15376/biores.13.4.7508-7518 
Zhang, J., Li, S., Liu, M., Yang, B., Wang, D. (2016). "Mathematical model of organic matter biodegradation in aerobic composting process of municipal sludge," Jiangsu Agricultural Sciences 44(2), 348-351. DOI:10.15889/j.issn.1002-1302.2016.02.102

Article submitted: November 20, 2019; Peer review completed: January 30, 2020;

Revised version received: February 19, 2020; Accepted: February 22, 2020; Published: February 27, 2020.

DOI: 10.15376/biores.15.2.2721-2734 